\title{
GET "HIP" AMERICA: USING THE "HEALTHY INDIANA PLAN" AS A MODEL FOR DECREASING THE NUMBER OF UNINSURED AMERICANS ONE STATE AT A TIME
}

\author{
Barbara E. Molargik-Fitch*
}

I. INTRODUCTION .....................................................................5

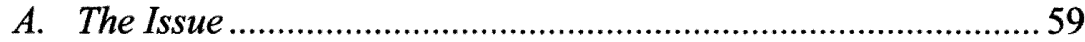

B. The Roadmap ......................................................................6 60

II. BACKGROUND AND FEATURES OF THE HEALTHY INDIANA PLAN ...60

A. The Passage and Objectives of HEA 1678............................... 60

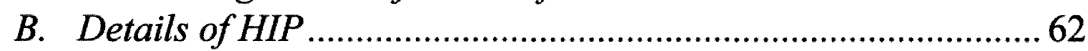

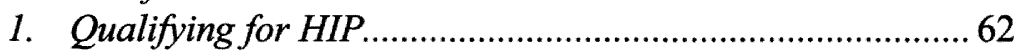

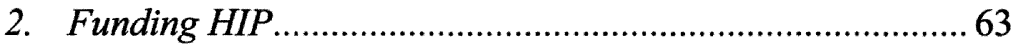

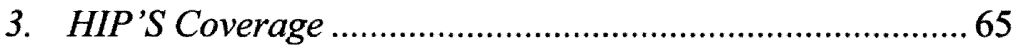

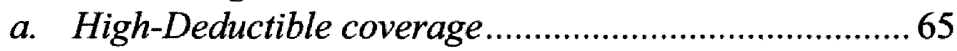

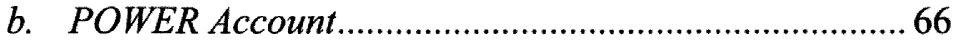

c. Preventative health care .............................................66

4. HIP's Insurers ..............................................................67

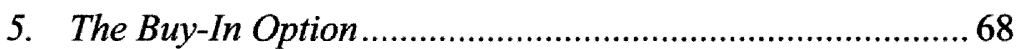

III. HIP'S MODEL OFFERS A MORE SUSTAINABLE ROUTE THAN

NATIONAL HEALTH CARE PROPOSALS TO ACHIEVE THE GOAL OF INSURING MORE AMERICANS....................................................69

A. The National Health Care Plans...............................................6 69

1. The United States Insurance Act of 2008 ...........................69

2. The Obama Reform Bill ............................................... 70

B. HIP's Unique, Realistic and Sustainable Nature .................... 72

IV. HIP IS A MODEL FOR MANY OTHER STATES STRUGGLING TO INSURE THEIR CITIZENS .............................................................. 73

A. HIP is a Model for Other States ......................................... 73

B. Unsuccessful State Plans ...................................................... 74

1. The California Plan............................................................ 74

2. The Wisconsin Plan ......................................................... 75

3. The Massachusetts Plan ...................................................... 75

4. The Washington Plan ...................................................... 77

5. The Maine Plan .............................................................. 78

C. Plans Similar to HIP and Based on Individual Choice and Market Competition ............................................................. 79

1. The Florida Plan ............................................................ 79

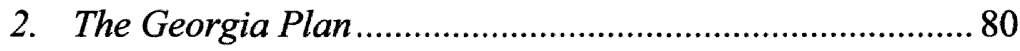

D. HIP Offers Something to Build On ...................................... 81

* J.D. candidate, 2010, Indiana University School of Law-Indianapolis; B.A., 2007, Indiana University-Bloomington. 
V. ON-Site HeAlth CARE Clinics OfFer AdDitional MEANS For INSURING MORE AMERICANS BY DECREASING THE COSTS STATE GOVERNMENTS MUST PAY IN HEALTH CARE EXPENSES....................8 82

A. Novia Careclinics, LLC. ("Novia"), Indianapolis, Indiana ........ 83

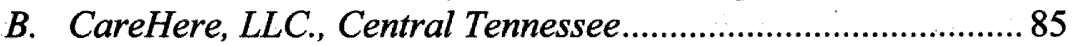

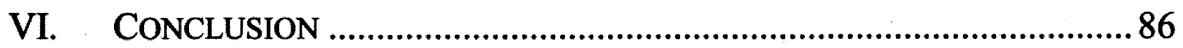

"I . . hope other states will follow Indiana's model of combining personal responsibility with public support to help those who are truly in need gain health coverage."

-U.S. Department of Health and Human Services Secretary Mike Leavitt

\section{INTRODUCTION}

One August afternoon Ms. Tammy Chandler carried her fifteen-dayold son to the Ambulatory Care Center in Huntsville, Alabama for a checkup. $^{2}$ While at the care center, Ms. Chandler was instructed to take her newborn infant to the hospital for emergency care immediately. ${ }^{3}$ Upon arriving at the hospital, the uninsured, distressed mother "was asked if she had either insurance or $\$ 54$ for the emergency room admission fee." Ms. Chandler had neither. As a result of her indigence, Ms. Chandler was told that her son could not be seen. ${ }^{5}$ A nurse at the hospital instructed her to go home and to give her sick infant Tylenol and a warm bath. ${ }^{6}$ Later that evening, however, Ms. Chandler returned to the hospital, once again, with her seriously ill child. ${ }^{7}$ Three hours later the infant was finally seen by a doctor. Unfortunately, because of the delayed medical treatment, the infant died from spinal meningitis the next day. ${ }^{8}$ Spinal meningitis, "an inflammation of the membranes that cover the brain and spinal cord," is a potentially fatal disease if not immediately treated with ingestion of antibiotics. ${ }^{9}$

1. Press Release, U.S. Dept. of Health \& Human Services, HHS Approves Medicaid Waiver to Create New Indiana Health Plan for Uninsured Hoosiers (Dec. 14, 2007), available at http://www.dhhs.gov/news/press/2007pres/12/20071214a.html (hereinafter "Press Release") 1989).

2. Chandler v. Hospital Authority of City of Huntsville, 548 So. 2d 1384, 1385 (Ala.

3. Id.

4. $I d$.

5. Id.

6. Id.

7. Id.

8. Chandler, 548 So.2d at 1385.

9. U.S. Dept. of Health \& Human Services, Centers for Disease Control \& Prevention, Meningitis Questions \& Answers, http://www.cdc.gov/meningitis/about/faq.html (last 


\section{A. The Issue}

The issue of health care coverage locally and nationally is not new. In 2007 , over 717,000 of Indiana's 6.26 million Hoosiers were without health insurance. ${ }^{10}$ The Healthy Indiana Plan ("HIP") was created to address the issue of health care coverage in Indiana, especially with regard to low income individuals like Ms. Chandler. HIP is vital for Indiana citizens, especially during times of economic downturn when Indiana citizens are losing health care coverage, particularly employer-sponsored health insurance. The percentage of Hoosiers covered by their employers' health care plans is dropping substantially. In fact, employer-sponsored health care plans "covered 70.5 percent of Indiana's under 65 population" in 2007. ${ }^{11}$ That was a substantial drop from the 75.7 percent employer-sponsored health care in 2001 . $^{12}$ Moreover, in the past few years, the entire country has been experiencing economic hardship. The number of people covered by employersponsored health care in 2007 was 59.3 percent, which was a decrease from 59.7 percent in $2006 .{ }^{13}$ "This continues a trend of decreasing employer sponsored coverage since 2000." "14 Furthermore, many states are experiencing a similar situation as in Indiana, where employers are eliminating health care plans. For example, in Minnesota fewer businesses provided health care coverage from 2001 to 2004, thus increasing the rate of uninsured residents from 5.4 percent in 2001 to 6.7 percent in $2004 .^{15}$ Additionally, looking at health care coverage overall, ten states had lower 2-yearaverage uninsured rates for 2006-2007 than their 2-year-average rates for 2004-2005. ${ }^{16}$ These states, along with their increase in uninsured, include: Kansas (+2.0), Kentucky (+1.6), Louisiana (+3.3), Mississippi (+3.0), Nebraska $(+2.3)$, New Jersey $(+1.4)$, New Mexico $(+2.6)$, New York $(+0.8)$, North Carolina $(+2.1)$, and Texas $(+0.9) .{ }^{17}$ Many states could use HIP as a model to develop an affordable health care plan that will help insure more of their citizens during this time of recession.

visited Jan. 6, 2010).

10. Daniel Lee, Fewer Hoosiers were Uninsured in 2007: Numbers Down Nationally, too; Experts Cite Expansion of Government Programs, THE INDIANAPOLIS STAR, August 27, 2008, at B08.

11. Report: Hoosiers Losing Health Insurance, GosHEN NEws, Oct. 14, 2008, http://www.goshennews.com/archivesearch/local_story_287105844.html (hereinafter "Losing Health Insurance").

12. Id.

13. Carman DeNavas-Walt, Bernadette D. Proctor \& Jessica Smith, Income, Poverty, and Health Insurance Coverage in the United States: 2007, U.S. Census Bureau at 19 (2008), available at http://www.census.gov/prod/2008pubs/p60-235.pdf.

14. Robert Wood Johnson Foundation, State Coverage Initiatives: Who's Uninsured? $\mathrm{http} / / / \mathrm{www}$.statecoverage.org/node/18\#_ftn1.

15. State's uninsured rate rises, as employers drop coverage, MINNEAPOLIS/ST. PAUL Bus. J., Feb. 25, 2005, http://twincities.bizjournals.com/twincities/stories/2005/02/21 /daily49.html.

16. DeNavas-Walt, supra, note 13 at 26.

17. Id. 
As explained herein, a realistic approach to substantially reducing the number of uninsured Americans nationwide is to offer health insurance coverage on a state-by-state basis which is based on market competition, personal responsibility, wellness, and public support, while also demanding a modest income-based premium. Such a plan makes it possible to insure more Americans while also being cost-efficient. If each state raises money to support its plan and crafts the plan to the very needs of its own citizens, like HIP, health care coverage for more Americans will be a more sustainable and affordable goal. Additionally, if each year states add new innovative aspects to their state plans to save money each year, and if those states continue to build on their plans annually to make them better, more Americans will be insured each year. On-site health care clinics, discussed in Party $\mathrm{V}$ of this note, exemplify an innovative feature which states may add to their health care plans and to their government agencies to save on health care costs.

\section{B. The Roadmap}

This Note discusses how HIP offers a health care model for other states struggling to provide health insurance for their citizens. In order to fully understand HIP's makeup and coverage, Section II of this Note discusses the background of HIP. Section III focuses on why HIP is a more sustainable model for decreasing the number of uninsured Americans than other federal health care plans that have been proposed or are currently being enacted. Section IV argues that HIP is a model for many other states that are struggling to insure their citizens by comparing HIP to state plans that have failed as well as state plans similar to HIP that are currently experiencing success. Finally, Section $\mathrm{V}$ takes a step into the future and discusses how adding "on-site" health care clinics to state health care plans and state governments may offer additional means for insuring more Americans by decreasing the overhead costs state governments must pay out in medical-related expenses.

\section{BACKGROUND AND FEATURES OF THE HEALTHY INDIANA PLAN}

\section{A. The Passage and Objectives of HEA 1678}

HIP, also known as the Indiana Check Up Plan, was introduced and passed by the Indiana General Assembly in April 2007 as part of the House Enrolled Act No. 1678, Public Law 218-2007 ("HEA 1678"). ${ }^{18}$ The stated

18. Family and Social Services Administration, A Check Up on the Indiana Check-Up Plan: HEA 1678, slide 16 (Sept. 30, 2008) http:/www.in.gov/fssa/hip/files /IndianaCheckUpPlan.pdf (last visited April 8, 2010) (hereinafter “A Check Up”); Indiana House of Representatives House Democrats, Indiana Check Up Plan, http://www.ai.org 
objective behind enacting HEA 1678 was to "advance health care policy in Indiana . . . and [to] reduce the state's high rate of smoking."19 When considering the passage of HEA 1678, the Indiana legislature was encouraged to reform its health care policy because of the alarming fact that Indiana had the second highest drop in employer-sponsored health insurance between 1999 and $2004 .^{20}$ Since 1990 , the uninsured population has increased by approximately 30 percent in Indiana. ${ }^{21}$ Additionally, Hoosiers had the second highest rate of smoking in $2008(26 \%),{ }^{22}$ eighteenth highest rate of obesity in $2008(63.5 \%),{ }^{23}$ and fourteenth highest rate of stroke and other cerebrovascular diseases in $2006(49.0 \%){ }^{24}$ To address these problems, the legislature enacted HEA 1678 to provide for various health care policy improvements.

Some of the health care highlights of HEA include: ${ }^{25}$

- tax credits related to small employer qualified wellness programs;

- an increase in cigarette tax by 44 cents per pack to fund various health related expenses;

- tax credits for employers for making a health benefit plan available to employees for the first two taxable years the health benefit plan available;

- an increase in the income limit for Medicaid eligibility for pregnant women;

- continuous eligibility of a child under Medicaid and the children's health insurance program (CHIP) until the child

/legislative/house_democrats/indiana_checkup_plan.html (last visited Feb. 9, 2009).

19. Governor Signs Healthy Indiana Bill, INSIDE INDIANA Bus., May 11, 2007, $\mathrm{http}: / \mathrm{www}$.insideindianabusiness.com/newsitem.asp?id=23285.

20. The Iowa Legislature General Assembly, The Healthy Indiana Plan House Enrolled Act 1678, slide 9 (2007) http://www.in.gov/fssa/hip/files/IndianaCheckUpPlan.pdf.

21. Id.

22. Kaiser Family Foundation-Statehealthfacts.org, Percent of Adults Who Smoke (2008) http://www.statehealthfacts.org/comparemaptable.jsp?ind $=80 \&$ cat $=2 \&$ sort $=a$ (last visited Jan. 8, 2010). The Kaiser Family Foundation is a non-profit and private operating foundation that focuses primarily on the major health care issues facing the U.S. and abroad. "Kaiser develops and runs its own research and communications programs, sometimes in partnership with other non-profit research organizations or major media companies," such as NPR or the Harvard School of Public Health. Additionally, Kaiser "serves as a non-partisan source of facts, information, and analysis for policymakers, the media, the health care community, and the public." Kaiser Family Foundation, About Us, http://www.kff.org/about /index2.cfm (last visited Jan. 8, 2010).

23. Kaiser Family Foundation-Statehealthfacts.org, Percent of Adults Who are Overweight or Obese (2009) http://www.statehealthfacts.org/comparemaptable.jsp?ind=89\&cat= 2\&sort=a (last visited Jan. 8, 2010).

24. Kaiser Family Foundation-Statehealthfacts.org, Number of Deaths Caused by Stroke and other Cerebrovascular Diseases (2006), http://www.statehealthfacts.org /comparemaptable.jsp?ind $=122 \&$ cat $=2 \&$ sort $=$ a.

25. Legislative Services Agency, DIGEST OF HB 1678 (2007), http://www.in.gov /apps/lsa/session/billwatch/billinfo?year=2007\&request=getBill\&docno=1678. 
becomes three years of age;

- establishment of the Indiana check-up plan (plan) [aka Healthy Indiana Plan] and the Indiana check-up plan trust fund;

- requirements for the state department of health to establish standards for and certify a small employer qualified wellness program;

- requirements for health insurers and health maintenance organizations to cover children up to 24 years old upon request;

- provisions certain small employers to join together to purchase group health insurance and allows the insurance commissioner and the office of the secretary of family and social services to develop a program to provide for such purchases;

- requirements that the Indiana comprehensive health insurance association administer plan benefits for high risk individuals insured under the plan;

- requirements for applications for necessary federal Medicaid approvals, including approval for presumptive eligibility for certain pregnant women and implementation of the plan;

- establishments of a plan task force; requirements for the health finance commission to study and report concerning several issues;

- and an allowance of appropriations for the act.

HIP is one of the many health care highlights included in HEA 1678. After HIP was passed in April 2007, the plan was quickly implemented. In August 2007, health insurance plans were selected for HIP (Anthem and MDWise), and in November 2007, a contract was signed with the health plan carriers. ${ }^{26}$ In December 2007, insurance carriers began accepting applications for HIP. ${ }^{27}$. Finally, on January 1, 2008 HIP was fully implemented. ${ }^{28}$ At that time, almost 7,000 applications have been received. ${ }^{29}$

\section{B. Details of HIP}

\section{Qualifying for HIP}

To qualify for HIP, individuals must be uninsured for at least 6 months and cannot be eligible for employer-sponsored health insurance,

26. Nat'l Governor's Association, Healthy Indiana Plan, slide 22, (2008) http:// www.nga.org/Files/pdf/0803HEALTHREFORMCOLLISI.PDF.

27. Id.

28. Id.

29. Id. 
Medicare, or regular Medicaid. ${ }^{30}$ HIP offers insurance to uninsured adult Hoosiers who are between the ages of 19 and 64 whose household incomes are between 22 and $200 \%$ of the Federal Poverty Level ("FPL"). ${ }^{31}$ This range is equivalent to approximately " $\$ 3,872$ to $\$ 35,200$ per year for a family of three in 2008. ${ }^{32}$ Hoosiers with incomes above $200 \%$ of the FPL are not eligible for HIP. They may, however, be eligible for the buy-in option explained in Section II(B)(5) of this Note. These requirements are intended to discourage insured Hoosiers from dropping their plans to join HIP, in the hope of preventing the plan from being overburdened with applicants. They also serve to discourage employers from dropping their plans so that their employees will join HIP. HIP cannot support every Hoosier; it was not built for universal-type coverage.

\section{Funding HIP}

One provision of HEA 1678 provides for an increase in cigarette taxes by 44 cents per pack to help finance HIP. ${ }^{33}$ Consequently, the cigarette tax increased from $\$ .555$ to $\$ .995$ per pack as of July 2, 2007. ${ }^{34}$ Since August $1,2007,27.05 \%$ of the money made from the cigarette tax has been dispersed to the HIP trust fund. ${ }^{35}$ This increase in cigarette tax is expected to lower the number of young smokers by approximately 40,000 , and the number of adult smokers by approximately $23,400 .^{36}$ In states that have high numbers of cigarette smokers, increasing the cigarette tax is one way to decrease the number of smokers, especially young smokers, while simultaneously funding a health care plan.

Moreover, those individuals who smoke less or quit smoking altogether will be healthier and will require less medical attention and treatment. Less overall treatment decreases total medical expenses and opens up additional funds for insuring more people. After all, in 1998, smoking-related

30. Family \& Social Services Administration., HIP: About the Plan, http://www.in.gov /fssa/hip/2344.htm (last visited Sept. 10, 2008) (hereinafter "About the Plan").

31. Family \& Social Services Administration, Healthy Indiana Plan: Frequently Asked Questions, http://www.in.gov/fssa/hip/ (last visited Oct. 25, 2008) (hereinafter "FAQs").

32. Kaiser Commission on Medicaid Facts, Summary of Healthy Indiana Plan: Key Facts and Issues (2008), at 2, http://www.kff.org/medicaid/upload/7786.pdf.

33. Healthy Indiana Plan The Issue: State launches coverage for low-income Hoosiers. Our View: Program could bring improved health to thousands, EVANSVILLE COURIER \& PRESs, January 2, 2008, available at http://www.courierpress.com/news/2008/jan/02 /healthy-indiana-plan-the-issue-state-launches-to/.

34. Lawrence Jegen, Recent Developments in Indiana Taxation, 41 IND. L. REV. 1271, 1291 (2008).

35. Id.

36. "Healthy Indiana Plan" to go live in January, HeAlth CARE Financial MANAGEMENT, October 2007, available at http://findarticles.com/p/articles/mi_m3257 /is_10_61/ai_n21040136/. (Health care Financial Management is the "[o]fficial magazine of the Health care Financial Management Association. Features the latest industry news for financial managers in all segments of the health care industry.) 
health care costs in the United States were approximately $\$ 75.5$ billion. $^{37}$ "For each of the approximately 46.5 million adult smokers in 1999[,] these costs represented an annual cost of . . \$1[,]623 in excess medical expenditures in addition to the . . \$ 1[,]760 in lost productivity." ${ }^{38}$ Decreasing the number of smokers would substantially trim this number especially considering "[h]ealth care costs for smokers at a given age are as much as 40 percent higher than those for nonsmokers."39

In addition, HIP collects low premiums from those insured by HIP. For example, a single adult with no children and an income ranging from $\$ 0$ to $\$ 10,200$ would pay $\$ 0$ to $\$ 204$ a year. ${ }^{40}$ A family of four with an income of $\$ 0$ to $\$ 20,650$ would pay $\$ 0$ to $\$ 413$ annually. ${ }^{41}$ Collecting these low premiums helps make the funding of HIP more manageable. Furthermore, the sliding scale used to determine the premiums is appropriate because those individuals who do not have jobs, such as students, can still obtain health care coverage without paying premiums they cannot afford. Some Hoosiers who do have an income, however, must contribute not more than 5 percent of their income to the plan to help offset expenses. ${ }^{42}$ This helps make HIP affordable and possible.

Furthermore, HIP is operated under $\$ 1115$ of the Medicaid waiver program and, thus, must be budget-neutral to the federal government. ${ }^{43}$ The details of this waiver, which have been approved by the Department of Health \& Human Services, are as follows:

In December 2007, Indiana received federal approval for a Medicaid waiver to implement the Healthy Indiana Plan. Under the plan, Indiana is using Medicaid funds to provide a benefit package modeled after a high-deductible heath plan and health savings account to previously uninsured very poor and low-income adults. Most enrollees are covered through managed care plans; those with certain high-risk medical conditions are covered through a separate fee-for-service plan. The waiver was approved for five years, from

37. World Health Organization, Tobacco and Poverty A Vicious Circle (2004), at 5, available at $\mathrm{http}: / / \mathrm{www}$.ingcat.org/linked\%20files/Poverty_en.pdf (citing Dept. of Health \& Human Services, Centers for Disease Control and Prevention, Annual smoking-attributable mortality, years of potential life lost, and economic costs-United States, 1995-1999,51 MORBIDITY AND MORTALITY WEEKLY REPORT, 300-3 (2002)).

38. World Health Organization, supra note 37, at 5.

39. Jan J. Barendregt, Luc Bonneux, \& Paul J. van der Maas, The Health Care Costs of Smoking, 337 THE NEW ENG. J. MED.1052, 1052 (1997).

40. FAQs, supra note 31 , at 10.

41. Id. at 11. According to FSSA data, a family of four consists of two adults and two children. Id.

42. FAQs, supra note 31, at 3.

43. Kaiser Commission on Medicaid Facts, supra note 32, at 6. 
January 1, 2008-December $31,2012 .^{44}$

During the five-year waiver period, HIP "cannot cost the federal government more than would have been spent without the waiver." 45 To assure this requirement is met, a per capita cap on federal funds was established, "which limits the amount of federal funds the state can receive for people covered under the waiver based on pre-set per person costs and annual growth rate." $" 46$

Indiana plans to offset the costs of expanding coverage by using a portion of its Disproportionate Share Hospital funds. ${ }^{47}$ Also, the state plans to save "in its existing Medicaid coverage for pregnant women, children, and parents." 48 To ensure budget neutrality is achieved, "the federal government established a per capita cap on federal funds for Healthy Indiana Plan expansion enrollees as well as pregnant women, children, and parents covered through Medicaid."49 Additionally, Indiana has agreed to achieve further savings of $\$ 15$ million over the five-year waiver period for which HIP was approved. ${ }^{50}$ This feature of HIP aids Indiana in maintaining a budget and prevents the risk of serious financial harm to the State Treasury.

\section{HIP'S Coverage}

HIP's benefits basically consist of three parts provided through managed care plans. ${ }^{51}$ These three components include: high-deductible coverage, a POWER account, and preventative health care.

\section{a. High-Deductible coverage}

First, HIP provides high-deductible coverage. ${ }^{52}$ After meeting a $\$ 1,100$ deductible, individuals are covered up to $\$ 300,000$ a year and up to

44. Id.

45. Id.

46. $I d$.

47. Id. See also U.S. Dept. of Health \& Human Services, Analysis of the Joint Distribution of Disproportionate Share Hospital Payments, http://aspe.hhs.gov/health/reports/02 /DSH/execsum.htm\#Introduction, ("The Medicare and Medicaid programs distribute extra payments to hospitals that treat a disproportionate share of indigent patients. The disproportionate share hospital (DSH) payment policies differ substantially between the two programs and, under Medicaid, across states as well. Nevertheless, the general objectives of each program are the same: to support the hospitals that are crucial to the health care safety net, and to preserve access to these hospitals for the respective program's enrollees.")

48. Kaiser Commission on Medicaid Facts, supra note 32, at 6.

49. Id. at 1 .

50. Id. at 6.

51. Id. at 3 .

52. Id. 
$\$ 1$ million in a lifetime for state-specified benefits. ${ }^{53}$ Upon meeting this deductible, individuals receive coverage for state-specified benefits, which include "inpatient and outpatient care, physician care, prescription drugs, home health care, and mental health care up to the caps." however, cover dental or vision care nor does it cover long-term skilled nursing care or pregnancy-related services. ${ }^{55}$

\section{b. POWER Account}

The second component of HIP is its Personal Wellness and Responsibility (POWER) Account feature. ${ }^{56}$ This account is HIP's "version of a Health Savings Account (HSA) and is used to cover the $\$ 1,100$ deductible." ${ }^{57}$ The POWER Account is funded by the enrollee or enrollee's employer, the state government, and the federal government and is administered by the enrollee's managed care plan. ${ }^{58}$ The POWER Account helps individuals pay for basic health services, such as regular doctor visits. Participants may make contributions to their POWER Accounts by check or money order, automatic bank draft, credit card, cash or through an employer contribution. ${ }^{59}$ However, failure of an individual to make the POWER Account contribution within 60 days will result in one of the following: (1) losing the coverage from HIP; (2) losing the chance to see an individual's doctor; (3) being removed from the HIP plan and having a portion of one's contribution returned; or (4) waiting twelve months to reapply for the HIP plan. $^{60}$

\section{c. Preventative health care}

Finally, HIP encourages preventative care. ${ }^{61}$ Indiana requires participating care plans to cover up to $\$ 500$ in preventative care each year. ${ }^{62}$ Preventative care is "not subject to the deductible and does not draw from the POWER Account." ${ }^{\text {"63 }}$ Additionally, with HIP coverage, "[p]arents are

53. Kaiser Commission on Medicaid Facts, supra note 32, at 3.

54. Id.

55. $I d$.

56. Id.

57. $I d$.

58. $I d$.

59. Family \& Social Services Administration, Healthy Indiana Plan: Health Plan Summary, http://www.in.gov/fssa/hip/files/MAXI542_IN_HIP-PlanChartDEC20.pdf (last visited February 8, 2009) (hereinafter "Health Plan Summary").

60. Kaiser Commission on Medicaid Facts, supra note 32, at 5; MDWise, Power Account, http://www.mdwise.org/HIP/members/poweraccount/ (last visited Feb. 19, 2009) [NTA: The MDWise website is not accessible. Consider eliminating this citation].

61. Kaiser Commission on Medicaid Facts, supra note 32, at 3.

62. Id.

63. Id. 
charged between $\$ 3$ and $\$ 25$ for an emergency room visit," emergency room fees being based on a parent's income. ${ }^{64}$ "[C]hildless adults are charged $\$ 25$ per visit" without consideration of income. ${ }^{65}$

\section{HIP's Insurers}

HIP has two health care insurers: MDWise (partnering with AmeriChoice) and Anthem Blue Cross and Blue Shield ("Anthem"). MDWise coverage is an extension of its Hoosier Healthwise Participating Provider Agreement. ${ }^{67}$ Characteristics of the MDWise agreement with HIP include, but are not limited to the following: \$25 co-pays for emergency room care for childless adults; emergency room care (for non-emergency services) based on family income level of adults with children; multiple POWER account methods of payment; care management services; disease management programs; enhanced services such as free unlimited preventative care services and free over-the-counter medicines; assistance with community resources and other needs; and educational programs. ${ }^{68}$

The Anthem agreement is an attachment to its Anthem Blue Cross and Blue Shield Provider Agreement and an Amendment to the Anthem Blue Cross and Blue Shield Professional Provider Agreement. ${ }^{69}$ This plan includes the following characteristics: $\$ 25$ co-pays for emergency room visits for childless adults; emergency room (for non-emergency services) visits for adults with children requiring a co-pay amount based on family income level; multiple POWER account methods of payment; care management services; disease management programs; ${ }^{70}$ community resource centers; and educational programs. $^{71}$

Enrollees of HIP must select a health care plan at the time of applica-

64. Id. at 3-4.

65. Id. at 4.

66. Healthy Indiana Plan (HIP) Resource Center, http://www.ismanet.org/HIP.htm (last visited Sept. 10, 2008) (hereinafter "HIP Resource Center").

67. Id.; Welcome to the Hoosier Healthwise Website (2007) http://www.healthcareforhoosiers.com/index.html. ("The Hoosier Healthwise Program is a health ( )care program for low income families, pregnant women, and children. It is sponsored by the state of Indiana through Family and Social Services Administration. The program covers such medical care as doctor visits, prescription drugs, mental health( )care, dental care, hospitalizations, surgeries, and family planning at little or no cost.")

68. Health Plan Summary, supra note 59.

69. HIP Resource Center, supra note 66.

70. Health Plan Summary, supra note 59.

71. Id. (HIP offers educational programs such as: "New Member Education Meetings at locations throughout the state[;] Online Health Risk Assessments [that] help [] [individuals] improve [their] health and give[] [them] a \$50 Gift Card for completion;;] Personalized Telephone Based Weight Management Program[s that] help[] [individuals] lose or gain weight, or stay at a healthy weight [;] Tobacco Treatment Program[s that] help[] [individuals] learn new behaviors, offers nicotine replacement gum and patches[; and] Health Coach Programs [that] offer telephone coaching sessions for certain health conditions.") 
tion, otherwise the state will assign a plan upon approval. ${ }^{72}$ Once enrollees are approved and are assigned a plan, they must stay on that plan for 12 months. ${ }^{73}$ As of June 2008, approximately 74 percent of enrollees chose the Anthem plan and approximately 24 percent chose MDWise. ${ }^{74}$

\section{The Buy-In Option}

Another unique characteristic of HIP is that it further permits a buy-in option for individuals and families who earn over $200 \%$ of the FPL. ${ }^{75}$ The buy-in option also allows for employers to pay for a portion of their employees' health insurance. ${ }^{76}$ In fact, "[e]mployers who do not currently offer any health plans of their own can pay up to 50 percent of the premiums for their employees who enroll in HIP." "77 Furthermore, "[a]s with the subsidized HIP program, [Hoosiers] accepted for the buy-in" option must also be uninsured for 6 months or more with no access to employer-sponsored health benefits. ${ }^{78}$ When determining the premium rate for the buy-in option, an individual's age, health status, and gender. ${ }^{79}$ The policy also looks at an individual's weight and overall health condition. ${ }^{80}$ By way of example, "[m]onthly premiums for a 25 -year-old male are around $\$ 125$, while a 60-year-old female would pay about $\$ 550$ per month."81

Additionally, the policy will cover some preexisting conditions. For example, it will cover diabetics who take pills only, but will not consider diabetics who take insulin. ${ }^{82}$ Also, to even apply for the buy-in option, applicants must have applied for and have been denied by HIP first. ${ }^{83}$ Additionally, according to FSSA spokesperson Elizabeth Sergener, approximately "140,000 Hoosiers are eligible for the HIP expansion." ${ }^{84}$ As of August 2008, Anthem is the only insurer participating in the buy-in option. ${ }^{85}$ MDWise is expected to also participate in the option in the near future. $^{86}$

72. Kaiser Commission on Medicaid Facts, supra note 31, at 4..

73. Id.

74. Id.

75. FAQs, supra note 31 , at 2.

76. Losing Health Insurance, supra note 11.

77. Id.

78. Bruce Goldfarb, Account-Based Healthy Indiana Program Expands With a Buy-in Option, AIS's Health Bus. DaILY, Aug. 5, 2008, http://www.aishealth.com/Bnow /hbd080608.html (last visited 2009).

79. Id.

80. Interview with Sales Representative, Anthem Blue Cross \& Blue Shield, Sales Hotline, at 1-800-622-4075 (Dec. 30, 2008) (hereinafter "Interview").

81. Goldfarb, supra note 78.

82. Interview, supra note 80.

83. Id.

84. Goldfarb, supra note 78.

85. Id.

86. Id. 
Individuals who would otherwise qualify for HIP may use the buy-in option if HIP reaches its maximum capacity of enrollees. ${ }^{87}$ In these instances, the HIP rates are available to such individuals, but the participants must pay the full costs. ${ }^{88}$ The buy-in option has not been promoted as much as the other portions of HIP have. It is, however, a unique part of the HIP program that could prove very beneficial to many uninsured Hoosiers.

\section{HIP's MODEL OFFERS A MORE SUSTAINABLE ROUTE THAN NATIONAL HEALTH CARE PROPOSALS TO ACHIEVE THE GOAL OF INSURING MORE AMERICANS}

Over 47 million Americans were uninsured in $2006{ }^{89}$ Furthermore, "[h] ealth care costs are predicted to increase from $\$ 1.6$ trillion in 2002 to $\$ 3.4$ trillion in 2013."90 "Many national health care plans have been proposed to provide Americans with access to health insurance and to address rising health care costs. However, a universal health care plan in the United States would likely be unsuccessful and would likely create a great financial burden on the country. It is questionable as to whether our country could sustain such an expensive plan for a long duration of time before it failed. In the early 1990s, Congress rejected President Clinton's universal health care plan because it would be too expensive to implement. ${ }^{91}$ As 2004 Health and Human Services Secretary Tommy Thompson stated, a universal health care plan is "unrealistic.," 92

\section{A. The National Health Care Plans}

\section{The United States Insurance Act of 2008}

The United States National Health Insurance Act of 2008 introduced in the House as H.R. 676 ("H.R. 676") "93 "[e]stablishe[d] the United States National Health Insurance (USNHI) Program (the Program) to provide all individuals residing in the United States and in U.S. territories with free health[ ]care that includes all medically necessary care, such as primary care and prevention, prescription drugs, emergency care, and men-

87. A Check Up, supra note 18 , at slide 15 .

88. Id.

89. Lee, supra note 10.

90. Mark E. Douglas, Finally Moving Beyond the Fiction: An Overview of the Recent State Rally for Health Care Reform, 5 IND. HEALTH L. REv. 277, 280-1 (2008).

91. Kristine Nwazota, Who Should Pay for Health Care, PBS, Jan. 19, 2004, http://www.pbs.org/newshour/extra/features/jan-june04/uninsured_1-19.html.

92. Id.

93. United States National Health Insurance Act (or the Expanded and Improved Medicare for All Act), H.R. 676, 110th Cong. (2008), available at http://www.govtrack.us /congress/bill.xpd?bill=h1 10-676\&tab=summary (hereinafter "H.R. 676"). 
tal health services."94 The plan allows a participant to choose a doctor or facility within the network. ${ }^{95}$ H.R. 676, however, prohibits private health care insurers from providing coverage duplicative of benefits it provides. ${ }^{96}$ H.R. 676 allows private "insurers to sell benefits that are not medically necessary, such as cosmetic surgery benefits." ${ }^{, 97}$ Allowing private insurers to provide coverage only for specific medical care may diminish the health insurance industry and may reduce the overall quality of health care coverage that is available to individuals.

To finance the plan, H.R. 676 seeks to establish the USNHI Trust Fund. ${ }^{98}$ This trust collects funds from the following: "(1) existing sources of Government revenues for health care; (2) [] increase[ed] personal income taxes on the top 5\% of income earners; (3) [] instituting a progressive excise tax on payroll and self-employment income; and (4) [] instituting a small tax on stock and bond transactions." 99

\section{The Obama Reform Bill}

Another national health care plan, of which was proposed by and signed into law ${ }^{100}$ by President Barack Obama on March 23, 2010, ${ }^{101}$ is known in short as the "Health Care Reform Bill" ("Reform Bill"). ${ }^{102}$ The Reform Bill is "the most far-reaching health legislation since the creation of the Medicare and Medicaid programs." 103 While the Reform Bill has been signed, additional changes will occur if a reconciliation bill is passed at a later time in addition to the Reform Bill. ${ }^{104}$

The Reform Bill mandates that Americans obtain health insurance by 2014 or they would be obligated to pay a penalty. ${ }^{105}$ For individuals, [t] penalty would start at $\$ 95$, or up to 1 percent of [one's] income, whichever is greater, and could rise to $\$ 695$, or up to 2.5 percent of [one's] income, by 2016." "[F] "[Fmilies have a limit of $\$ 2,085 .{ }^{107}$ Some individuals would

94. Id.

95. Id.

96. Id.

97. Id.

98. Id.

99. H.R. 676, supra note 93.

100. Reform bill was signed into law as Public Law No: 111-148. See Thomas (Library of Congress), H.R. 3590, Major Actions, http://thomas.loc.gov/cgi-bin/bdquery /z?d111:HR03590:@@@R (last visited March 31, 2010) (hereinafter “Major Actions").

101. Major Actions, supra note 100.

102. Thomas (Library of Congress), H.R.3590, Titles, http://thomas.loc.gov/cgi-bin /bdquery/z?d111:HR03590:@@@T (last visited March 31,2010).

103. Phil Galewitz, Consumers Guide to Health Reform, Kaiser Health News, March 23, 2010, http://www.kaiserhealthnews.org/Stories/2010/March/22/consumers-guide-healthreform. . $\mathrm{spx}=$ (hereinafter "Consumers Guide").

104. Id.

105. Id.

106. Id. 
be exempted from the individual mandate for financial hardship or religious beliefs or if they are American Indians. ${ }^{108}$

Beginning in 2014, the state-federal program for the poor and disabled would be substantially increased, so that individuals with income less than 133 percent of the FPL, may be eligible for the Medicaid program. ${ }^{109}$ Individuals with income greater 133 percent of the FPL, may acquire government subsidies to help pay for a private insurance plan 'that would be sold in the new state-based insurance marketplaces, called exchanges, slated to begin in 2014."110 These subsidies would be available for individuals and families making between 133 percent and 400 percent of the poverty level. $^{111}$

Furthermore, individuals with preexisting conditions would be able to obtain health insurance easier because "insurers would be barred from rejecting applicants based on health status" beginning in 2014 when the exchanges are operating. ${ }^{112}$ During the transition period, there would be "a temporary high-risk insurance pool for people with medical problems who have been previously rejected by insurers and have been uninsured for at least [6] months."113 Additionally, individuals younger than 26 would be able to stay on their parent's insurance plans as long as they are not offered health coverage at work. ${ }^{114}$ Individuals over 65 would notice an improvement in the Medicare prescription-drug benefit. ${ }^{115}$ However, government funding of the Medicare Advantage, ${ }^{116}$ "would be cut sharply starting in 2011."117 This means that the 10 million individuals enrolled in Medicare Advantage would "lose extra benefits that many of the plans offer, such as free eyeglasses, hearing aids[,] and gym memberships."118

The Reform Bill would require firms with more than 50 employees to pay a fee of up to $\$ 2,000$ per full-time employee if any of their workers got government-subsidized insurance coverage in the exchanges instead of from the employer. ${ }^{119}$ The first 30 workers would not be included in the assessment. ${ }^{120}$ In contrast, companies with fewer than 50 workers would not face any penalties for not offering health insurance to its employees. ${ }^{121}$ Additionally, tax credits could be available to companies to help them buy insur-

107. $I d$.

108. Id.

109. Galewitz, supra note 103.

110. Id.

111. Id.

112. Id.

113. Id.

114. Id.

115. Galewitz, supra note 103.

116. Id. (Medicare Advantage is the private-plan part of Medicare.)

117. Galewitz, supra note 103.

118. Id.

119. Id.

120. Id.

121. Id. 
ance if they have 25 or fewer employees and a workforce with an average wage up to $\$ 50,000$. $^{122}$

The Reform Bill will cost approximately $\$ 938$ billion over the next 10 years ${ }^{123}$ and is expected to extend health care coverage to 32 million additional Americans by 2019. ${ }^{124}$ Those individuals with higher incomes will have to pay higher taxes. ${ }^{125}$ Individuals earning more than $\$ 200,000$ a year and couples earning more than $\$ 250,000$ will pay a 2 percent higher Medicare payroll tax which is up from the current $1.45 \%$ tax. ${ }^{126}$ Furthermore, the Reform Bill will impose "a 40 percent excise tax on the portion of employer-sponsored health coverage (excluding dental and vision) that exceeds $\$ 10,200$ a year for individuals and \$27,500 for families."127 Future health insurance premiums will be hard to predict are the subject of much debate in the passage of the Reform Bill. ${ }^{128}$

\section{B. HIP's Unique, Realistic and Sustainable Nature}

HIP is different and more realistic to implement than H.R. 676 and the Reform Bill. HIP is a more sustainable plan because it requires each participant to make a modest income-based financial contribution and focuses on combining personal responsibility with public support. Also, it does not abolish employer-sponsored health care benefits nor does it mandate individuals to obtain health insurance as do the national plans mentioned in Part III(A)(1) and (2) of this Note. HIP recognizes that insuring all Indiana citizens solely through HIP coverage is not a realistic goal. Gradually insuring Hoosiers who cannot obtain insurance elsewhere, while also encouraging employers to keep their health care plans for their employees, is a more sustainable route to increasing access to medical care. HIP also "provides incentives for participants to stay healthy, be value and cost-conscious, and to utilize services in a cost-efficient manner." 29 Additionally, by taxing a habit that is very destructive to health, Indiana will be able to finance a health care plan while also discouraging smoking at the same time. Also, instead of increasing income taxes for residents, as does the Reform Bill, HIP requires those insured by HIP to pay an income-based premium.

National health care sounds ideal initially. However, the reality is that if the government insures the entire country, which included approximately $307,212,123$ people in $2009,{ }^{130}$ the government may be forced to substitute

122. Id.

123. Galewitz, supra note 103.

124. Id.

125. Id.

126. Id.

127. Id.

128. Id.

129. FAQs, supra note 31 , at 1 .

130. CIA-The World Factbook, The United States (July 2009), https://www.cia.gov 
quality for quantity, and limit who and where citizens may choose to obtain health care. Also, by substituting quality for quantity, many health care professionals, such as specialists, may struggle to stay in business. Specialists are more expensive, and a national health care plan may wish to curtail spending for specialists even though specialist care is often critical for receiving proper health care.

The Reform Bill has numerous positive aspects such as barring insurance companies from denying coverage based on preexisting conditions. Nevertheless, the plan is expensive as it will cost approximately $\$ 938$ billion over 10 years to make the health care reforms it projects to make. ${ }^{131}$ The Reform Bill also seeks to mandate the entire country to obtain health insurance, penalizing those who do not obtain insurance, rather than looking at the various needs of individual states. Instead, the majority of health care decision making should be left to the states, because they are in a better place to individually address the issue of financing and creating health care programs within their borders. For example, if a state has a high rate of alcoholism, drunk drivers, and underage drinkers, it could increase the tax on alcohol. If a state has experienced a rapid increase in the number of casinos being built within its borders, it could capitalize on this expanding industry and increase the tax on the winnings at such casinos. Each state is different and has different needs. These innovative ideas allow for a more customized, stable, and effective health insurance plan, than does national health care, which is why this Note finds that HIP offers an excellent health care model for other states to follow to decrease the number of uninsured Americans.

\section{HIP IS A MOdEL FOR MANY OTHER STATES STRUGGLING TO INSURE THEIR CITIZENS}

\section{A. HIP is a Model for Other States}

HIP offers a model for other states to follow to connect more citizens in each state to health care. According to U.S. Department of Health \& Human Services Secretary Mike Leavitt, HIP “"is a forward-thinking plan to reduce the numbers of uninsured Indiana residents ....",132 Secretary Leavitt went on to say, " [HIP] is an excellent example of what can be done now in the states to advance this important objective." " "[I] hope other states will follow Indiana's model of combining personal responsibility with public support to help those who are truly in need gain health coverage." 133 HIP is a "forward-thinking plan" because it is different from plans such as Medicaid and Medicare, in part, because it has strictly limited bene-

/library/publications/the-world-factbook/print/us.html.

131. Consumers Guide, supra note 103.

132. Press Release, supra note 1.

133. Id. 
fits and services where recipients have the incentive to be responsible for their health status, to be mindful of costs, and to utilize health care services efficiently. ${ }^{134}$

\section{B. Unsuccessful State Plans}

\section{The California Plan}

California proposed a statewide health care plan in 2007 ("California Plan"). ${ }^{135}$ This plan required all California residents "not on Medicare or MediCal (California's Medicaid program)" to acquire insurance. ${ }^{136}$ Those who could not afford the insurance would be offered subsidies. ${ }^{137}$ However, it was debated whether the subsidies would be substantial enough to cover lower-income families. ${ }^{138}$ Opponents of the plan argued that it "wasn't fair to penalize [low-income citizens] for coverage they couldn't afford."139 As one California senator stated, the California Plan is "“a knife in the throat of the working poor." 140 The California Plan also placed a mandate on employers to do one of two things: either to provide health insurance for their employees, or to pay an additional business tax of 10 percent to the state. ${ }^{141}$ This employer mandate was applicable to businesses with more than 9 employees. ${ }^{142}$ Also, the California Plan required insurers to sell their product to anyone asking for it without consideration of an individual's medical condition. ${ }^{143}$

The California Plan was funded by increasing payroll tax by 6 percent, implementing a 2 percent tax on physicians and a 4 percent tax on hospitals, and adding an additional $\$ 1.50$ to $\$ 2.00$ per pack tax on cigarettes. ${ }^{144}$ The total cost of the plan was predicted to be $\$ 14$ billion annually. ${ }^{145}$ Although

134. FAQs, supra note 31 , at 1.

135. Robert Stark, What Works and What Doesn't: A Review of Health Care Reform in the States, Washington Policy Center for Health Care, August 2008, at 9, available at www.washingtonpolicy.org/Centers/healthcare/policybrief/StateHealthCareReforms.pdf.

(Dr. Roger Stark is a health care policy analyst with the Washington Policy Center ("WPC"). The WPC is an independent and non-partisan research and education organization that publishes studies, sponsors events and conferences, and educates citizens on public policy issues.) Washington Policy Center, About Us, http://www.washingtonpolicy.org/aboutus /missionstatement.html.

136. $I d$.

137. Op-Ed, Terminated, WALL ST. J., Jan. 30. 2008, at A16, available at http://online.wsj.com/article/SB120165320966126977.html?mod=opinion_journal_main_stories.

138. Id.

139. Id.

140. $I d$.

141. Stark, supra note 135 , at 6.

142. Id.

143. $I d$.

144. Id.

145. $I d$. 
California's increase on the cost of cigarettes is a forward-thinking idea, requiring citizens to pay an augmented payroll tax is burdensome, especially in light of the current economic climate in which residents may not have additional funds to either pay higher taxes or purchase compulsory health insurance.

\section{The Wisconsin Plan}

Wisconsin proposed a health care plan ("Wisconsin Plan") in 2008, but it failed to pass. ${ }^{146}$ If implemented, the plan would have required "coverage for all [citizens] not enrolled in an existing government program such as Medicare or Medicaid."147 The Wisconsin Plan's goal was to offer universal coverage while also lowering costs. The plan was funded by a new 14.5 percent payroll tax, in addition to the " 15.3 percent tax [that] workers already pay to fund Social Security and Medicare."148 In its first year after passage, Wisconsin legislators estimated that the Wisconsin Plan would cost $\$ 15.2$ billion. $^{149}$ This would have doubled the state budget. ${ }^{150}$

\section{The Massachusetts Plan}

One state plan that has proved to be unsuccessful is the Massachusetts" "Connector Plan" ("Massachusetts Plan"). ${ }^{151}$ This plan was passed in the spring of 2006 for the purpose of dealing with increased health care costs in Massachusetts. ${ }^{152}$ The plan intended to cover the estimated 550,000 uninsured Massachusetts residents. ${ }^{153}$ Proponents of the plan were determined that "the state's uninsured population would be reduced to zero."

The Massachusetts Plan requires "every resident between the ages of 18 and 64 to purchase a state-defined health insurance policy" beginning July $1,2007 .{ }^{155}$ Those individuals who did not purchase a policy by December 2007 would be penalized $\$ 219$ through tax filings. ${ }^{156}$ The penalty would increase in 2008 to 50 percent of the average cost of a health insurance plan in the geographic region where the person lives. ${ }^{157}$

146. Id. at 7 .

147. Id.

148. Id.

149. Id.

150. Id.

151. Id.at 5 .

152. Id.

153. Id.

154. Id.

155. Id. See also Kaiser Commission on Medicaid Facts, Massachusetts Health Care Reform: Two Years Later (2008) http://www.kff.org/uninsured/upload/7777.pdf. (herineafter "Kaiser on Massachusetts").

156. Kaiser on Massachusetts, supra note 155.

157. Id. 
Additionally, all employers with more than 11 workers were required to make a "fair and reasonable" contribution to their employees health insurance coverage or pay a "Fair Share" contribution of up to $\$ 295$ per employee each year. ${ }^{158}$ Massachusetts "provides subsidies for residents with incomes less than 300 percent of the [FPL]."159 Residents with an income below this percentage do not pay anything. ${ }^{160}$ Additionally, the Massachusetts Plan took over "the role of private-sector insurance agents by matching individuals with state-approved health plans." 161 "[A]pproximately 350,000 people who previously had no insurance are covered by the" Massachusetts Plan. ${ }^{162}$ A majority of the enrollees, however, are also in an entitlement program that is subsidized by the state. As a result, "[i]ndividual private plans are not selling well."

Furthermore, the Massachusetts Plan does not have any measures in place to deal with the state's rapidly increasing health care costs. ${ }^{164}$ Additionally, the plan has caused "a dramatic increase in demand for medical services, to the point where primary care doctors are in short supply. Waiting times to see a family physician are up to [1] year in parts of western Massachusetts." "165 Already, there is an early budget overrun of 30 percent. $^{166}$ The Massachusetts governor asked for $\$ 869$ million in additional funds for 2009. ${ }^{167}$ This amount is about $\$ 400$ million more than 2008 and may still fall short." ${ }^{168}$ However, that number may "reach as high as $\$ 1.1$ billion."169 In the next ten years, the over-run cost of the Massachusetts Plan is estimated to reach $\$ 4$ billion. ${ }^{170}$ Resultantly, there is a "proposed tax increase of $\$ 129$ million."171 Additionally, to control costs, the legislature is "considering cutting payments to doctors, increasing the special tax on employers (currently $\$ 295$ a year), increasing the state tobacco tax, and imposing additional regulations on insurers and drug companies."172 Currently, there is no proposal to decrease mandates on individual insurance plans. As a result, Massachusetts insurance carriers are finding it difficult to offer low-cost plans. ${ }^{173}$

158. Id.

159. Stark, supra note 135 , at 6.

160. $I d$.

161. Id.

162. Id.

163. $I d$.

164. Id.

165. Stark, supra note 135 , at 6.

166. Id.

167. Id. See also Kaiser on Massachusetts, supra note 155.

168. Id.

169. Stark, supra note 135 at 6.

170. Id.

171. Id.

172. Id.

173. Id. 
Initially, advocates of the Massachusetts Plan claimed it would lower health care costs to achieve universal coverage. It has instead "increased costs for individuals and the state, in addition to reducing revenues for doctors and hospitals."174 Massachusetts officials are admitting that their " "universal coverage is not likely to be universal any time soon.",175 Nevertheless, benefits are increasing for individuals because the state government is requiring all patients to purchase certain "benefits" that they will never use and would never have voluntarily chosen in a free market. ${ }^{176}$ "For example, the Massachusetts Plan currently requires insurance plans to... [cover] in vitro fertilization, blood lead poisoning treatment, and chiropractor services" even if these services are not needed by the insured.. ${ }^{177}$ The mandated benefits of the Massachusetts Plan have raised health care insurance costs by at least 23 percent. $^{178}$

\section{The Washington Plan}

In 1993 the Washington state legislature passed health care reform legislation, which was known as the Washington State Health Plan ("Washington Plan") in response to Washington's 600,000 uninsured residents. ${ }^{179}$ The plan would require all residents to join a managed competition plan if they were not receiving coverage through Medicare. ${ }^{180}$ The underlying goal of the Washington Plan was to provide universal coverage. The plan included the following elements: "(1) Price controls in the form of stateimposed caps on insurance premiums; (2) Statewide community ratings and universal access; (3) New mandates on employers and individuals; (4) A guaranteed issue law, and; (5) Increased emphasis on public health and prevention." 181 The Washington Plan added more mandates and restrictions on employers and individuals, gave state government more control over health care, and added a new powerful state bureaucracy. ${ }^{182}$

The Washington Plan ultimately created overwhelmingly negative consequences. ${ }^{183}$ After the plan was enacted, 14 health insurance carriers left the state. ${ }^{184}$ Those carriers that remained were forced to raise their rates

174. Paul Hseih, Mandatory Health Insurance: Wrong for Massachusetts, Wrong for America, 3 The ObJEctive Standard: A JouRnal of Culture AND Politics 3, (2008), available at $\mathrm{http}: / / \mathrm{www}$.theobjectivestandard.com/issues/2008-fall/mandatory-health-insurance.asp (last visited Apr. 8, 2010).

175. Id.

176. Id.

177. Id.

178. Id.

179. Stark, supra note 135 , at 2 .

180. Id.

181. Id.

182. Id.

183. Id. at 3 .

184. Id. 
up to 40 percent. $^{185}$ The number of uninsured actually rose instead of decreasing. ${ }^{186}$ The guaranteed issue provision in the plan also caused severe consequences. ${ }^{187}$ This law required carriers to sell their product to anyone, regardless of their medical history. ${ }^{188}$ For instance, a woman who becomes pregnant could purchase an insurance plan, use it during her pregnancy and immediately after giving birth, then withdraw from coverage when it is no longer needed. ${ }^{189}$ The community rating law mandated "that premiums charged by [carriers] be an average of all premiums...in a given region." 190 The community rating and guaranteed issue rules caused two events to happen. ${ }^{191}$ First, they encouraged people who were healthy to avoid buying health insurance. ${ }^{192}$ Second, they encouraged people to avoid buying health insurance until they got sick. ${ }^{193}$ These rules resulted in higher health insurance costs for everyone. ${ }^{194}$ Therefore, by 1994 , there was a citizen revolt at the voting booths. ${ }^{195}$ "The governing party lost its majority, and the governor who had signed the reform the plan was forced to approve a repeal of the program." "The Washington health insurance market is still recuperating from the detrimental consequences results of the Washington Plan ${ }^{197}$

\section{The Maine Plan}

In 2005, Maine passed a health care reform plan known as the Dirigo Health Plan ("Maine Plan"). ${ }^{198}$ This plan provides coverage beyond MaineCare, Maine's Medicaid Program. ${ }^{199}$ The plan's goals were to "expand access to care, contain costs, and quality" of health care. ${ }^{200}$ Initially the Maine Plan was "available to uninsured individuals and to business owners with fewer than 50 employees." 201 The Maine Plan includes a guaranteed

185. Id.

186. Id.

187. Id.

188: Id.

189. Stark, supra note 135 , at 3 .

190. Id.

191. Id.

192. Id.

193. Id.

194. Id.

195. Stark, supra note 135 , at 3 .

196. Id.

197. Id.

198. Id. at 7 .

199. Paul Saucier, MaineCare and Its Role in Maine's Healthcare System, The Kaiser Commission on Medicaid and the Uninsured, January 2005, at 5, available at http://www.kff.org/medicaid/upload/MaineCare-and-Its-Role-in-Maine-s-HealthcareSystem-Report.pdf.

200. Id.

201. Stark, supra note 135 , at 7 . 
issue requirement. ${ }^{202}$ Funding for the Maine Plan is provided by individuals who enroll in the program, "a one-time $\$ 53$ million state 'grant,' and federal subsidies for people earning less than 200 percent of the [FPL]." ${ }^{203}$ Also, insurance companies are taxed "four percent on all health insurance policies sold in the state." 204 The plan includes Certificate of Need restrictions, which makes it difficult for doctors and clinics to provide medical services that are current and new. ${ }^{205}$

Unfortunately, the Maine Plan has not provided the health coverage that it initially promised, and has been unsuccessful at controlling health care costs. ${ }^{206}$ Presently, "only 13,000 people are covered [under the Maine Plan] at a cost of over $\$ 50$ million per year, and the program is also no longer accepting new enrollees." ${ }^{207}$

\section{Plans Similar to HIP and Based on Individual Choice and Market Com- petition}

In contrast, two plans that have been passed in states which are similar to HIP include Georgia's health care plan ("the Georgia Plan") and Florida's health care plan ("the Florida Plan.") ${ }^{208}$ Both of these plans use individual choice and market competition to lower costs and are currently experiencing success. ${ }^{209}$ HIP, the Georgia Plan, and the Florida Plan take a different approach to health care reform. ${ }^{210}$ These three plans "move decision-making about health care to the individual, work with market forces, and create voluntary incentives that increase choice and expand access to health care coverage." ${ }^{211}$ Additionally, these plans do not promote universal coverage. "Instead, they direct reform policies toward people who need the most help in getting health coverage: low-income families, the chronically ill and the uninsured."212

\section{The Florida Plan}

The Florida Plan was enacted in 2008 to provide health care coverage for the 20 percent of uninsured Florida residents. ${ }^{213}$ The plan is voluntary

207. Stark, supra note 135 , at 7 .

208. Id. at 10 .

209. Id at $10-11$.

210. Id. at 2 .

211. Id.

212. Id. at 10 .

213. Id. 
and available to residents earning less than 300 percent of the FPL who have, like HIP requires, been uninsured for more than 6 months. ${ }^{214}$ The Florida Plan helps lower costs by creating increased competition among private insurers, which encourages them "to offer attractively-priced plans ...."215 This contrasts plans that mandate coverage because such mandates actually add 15 to 25 percent to health care coverage costs. ${ }^{216}$ The Florida Plan includes: "preventative and primary care services, such as...office visits, outpatient and inpatient surgery, urgent care, prescription drugs, durable medical equipment and diabetic supplies."217 The Florida Plan, however, does "not cover prolonged hospital stays or specialty care." ${ }^{218}$ As of 2008,9 insurers submitted proposals to participate in the program, which has proven to be successful thus far. ${ }^{219}$

\section{The Georgia Plan}

The Georgia Plan was enacted in May 2008 as a voluntary plan which "encourages use of...low-cost Health Savings Accounts (HSAs) to provide health care coverage."220 Under this plan, residents are allowed to deduct their HSA-related insurance premiums from their income when they calculate their state income tax liability. ${ }^{221}$ This feature results in a "[6] percent reduction in the cost of health care coverage for individuals." ${ }^{222}$ Another attractive feature of the Georgia plan is that it provides a $\$ 250$ tax credit per worker to small business owners with 50 or fewer employees who offer HSA coverage to their employees. ${ }^{223}$ Georgia legislators "repealed state and local taxes on HSA-based insurance premiums," which further lowers the market price of HSA plans. ${ }^{224}$ Legislators also predict that its new plan "will reduce the cost of HSA-based insurance plans by $\$ 146$ million a year, lower taxes for employees by $\$ 64.8$ million a year, and save workers $\$ 6.7$ million a year." ${ }^{, 25}$ Georgia is expecting to expand health care coverage to approximately 500,000 uninsured residents. ${ }^{226}$

214. Id.

215. $I d$.

216. $I d$.

217. $I d$.

218. Stark, supra note 135 , at 10.

219. Stark, supra note 135 , at 11 .

220. Id.

221. Id.

222. $I d$.

223. $I d$.

224. $I d$.

225. Stark, supra note 135, at 11 (citing Ron Bachman, Senior Fellow, Impact of Insuring 500,000 Georgians Previously Uninsured, CENTER FOR HEALTH TRANSFORMATION, May 9, 2008, available at http://www.healthtransformation.net/galleries/wp-consumerism /TheEconomicImpactofHB977.pdf.

226. Stark, supra note 135 , at 11 . 


\section{HIP Offers Something to Build On}

HIP, along with the Georgia and Florida plans, does not require much expanded government control. After all, health care problems do not necessarily improve with more control from the government. ${ }^{227}$ Furthermore, $^{2}$ mandates for health insurance coverage cause severe problems as well. ${ }^{228}$ Mandates "restrict choice in type and amount of insurance" that an individual needs or can afford without taking into account each individual's situation. $^{229}$

Moreover, another problem faced by some states is price control. ${ }^{230}$ "Community rating, guaranteed issue, and insurance premium caps are efforts by policymakers to limit rising costs by simply banning price increases."231 However, these types of price controls are generally unsuccessful because "prices are set by the supply and demand" of the market. ${ }^{232}$

Specifically, the Massachusetts Plan does nothing to help those who lose their insurance coverage when they become unemployed. Likewise, the Wisconsin Plan has its shortcomings, evidenced by the resulting extreme amount of debt that the state has incurred. HIP starts out with a capacity that can be built on over time, instead of a plan that covers everyone all at once. Also, HIP neither increases personal income taxes to pay for the plan nor places a mandate on citizens to purchase health care regardless of whether or not they can afford it. Thus, universal plans, both state and national, are not the answer.

Residents should have the ability to choose which plan they want. HIP has been in existence only since January 2008 , but it is currently a leading model for state health care plans. Furthermore,

[t]he implementation of the Healthy Indiana Plan in 2007 offers something to build on. It extends insurance to some low-income Hoosiers, offers tax credits for businesses with qualified wellness programs and encourages smokers to quit. But with many still uninsured, there's more left to do. In 2009, the governor must explore options to go further. ${ }^{233}$

Indiana is doing its part in decreasing the number of uninsured Ameri-

227. Id.

228. Id. at 12.

229. Id.

230. $I d$.

231. Id.

232. Id.

233. Kevin M. Brinegar, Letters to the Editor, State Should Help with Health Care,JouRNAL GAZETTE, August 27, 2008, at 15A, available at 2008 WLNR 16202790. 
cans by insuring Hoosiers through HIP, but it too has room for improvement. According to FSSA Secretary Mitch Roob, " $[t]$ he program is signed for people who don't have access to employer-sponsored health care."'234 In fact, HIP obtains "enough funding to cover about 130,000 needy Hoosiers." 235 HIP is still flawed in that it does not address employees who cannot afford the health care benefits offered by their employers. Additionally, approximately half of the 41,948 people enrolled in HIP as of December 2008 are Hoosiers without dependent children. ${ }^{236}$ This is problematic because the cap on enrollees without dependent children is 34,000 , while there is not a cap for adults with dependent children. ${ }^{237}$

Nonetheless, even with its imperfections, HIP is making history. FSSA Secretary Mitch Roob is pleased with the results of HIP in its first year. ${ }^{238}$ He stated, "'[t]o go from a standing start to 40,000 insured Hoosiers is pretty good, and we're still going, we're still growing." "239 Secretary Roob further stated, "HIP was never designed to be the end-all and beall... It was a large and important step out onto the ice, but it was the first step." 240 As of December 2008, the state of Indiana has received 100,657 applications since beginning the program in January $2008 .{ }^{241}$ Even though HIP does not insure every Hoosier, or even every applicant, the program is setting an example for other states to follow. ${ }^{242}$ No other state has formed a plan quite like HIP. ${ }^{243}$ HIP is a first step upon which it can be expanded like the Georgia Plan, which is expected to increase its coverage to 500,000 people. ${ }^{244}$ HIP is a realistic model for other states struggling to insure their citizens, is superior to many other state health care plans, and is taking a vital step, along with states that have enacted plans similar to HIP, towards decreasing the number of uninsured Americans.

\section{ON-Site HeAlth CARE Clinics OfFER AdDitional MEANS FOR INSURING MORE AMERICANS BY DECREASING THE COSTS STATE GOVERNMENTS MUST PAY IN HEALTH CARE EXPENSES}

An additional creative proposition that could decrease the amount of

234. Brandi Watters, FSSA Admits Problems with HIP: State Confident in Most of the Progress Being Made, THE HERALD Bulletin, May 26, 2008, available at http:// www.heraldbulletin.com/archivesearch/local_story_147193929.html.

235. Id.

236. Shari Rudaysky, State health plan for uninsured nearing capacity for some adults, THE INDIANAPOLIS STAR, Dec. 29, 2008, 2008 WLNR 24894034.

237. Id.

238. Id.

239. Id.

240. Id.

241. Id.

242. Watters, supra note 234.

243. Id.

244. Stark, supra note 135, at 11. 
health care costs that state governments pay out for their health care plans includes implementing health care clinics, which offer preventative health care, into government agencies and into state sponsored health care plans. These on-site health care clinics would allow for an increase in the capacity to insure more Americans by decreasing health care costs. A growing number of companies are providing on-site health care clinics with services such as free check-ups, screenings, and prescription drugs. ${ }^{245}$ Some companies, "such as Intel Corp., Walt Disney Co., and Toyota Motor Corp., are opening...on-site" clinics for their employees that are "staffed by physicians and nurses that offer primary-care services."246 Novia CareClinics, LLC ("Novia"), based in Indianapolis, Indiana and CareHere, LLC ("CareHere"), based in central Tennessee, are two companies that manage and implement these type of on-site clinics into businesses and government agencies.

\section{A. Novia Careclinics,LLC. ("Novia"), Indianapolis, Indiana}

Novia manages and creates on-site health care clinics for employers. These on-site clinics provide primary health care services to employees and their dependents. ${ }^{247}$ Novia's management services allow employers to reduce the costs of insurance coverage while also providing excellent insurance benefits to employees. ${ }^{248}$ Some of the services Novia provides include: "[c]linic operations management, including inventory maintenance and staffing[; o]n-line scheduling and electronic medical records systems[;] Individual Health Risk Assessments[; p]re-disease management and educational reach-out programs[; h]ealth coaching[; a]ssistance in chronic disease management[; and]... [e]mployee population health management and accountability."249

Novia decreases health care costs for employers by providing on-thejob care. The clinics are wellness-based, and the goal is to encourage employees to stay healthy while also decreasing health care costs. The clinics are staffed by physicians recruited from the employer's local community. ${ }^{250}$ Employees and their families have access to the clinics at no additional cost. $^{251}$ The idea of such health care clinics is to help decrease the amount

245. M.P. McQueen, Workers Get Health Care at the Office, Wall St. J., Nov. 18, 2008, available at http://online:wsj.com/article/SB122696833222435529.html.

246. Id.

247. Welcome to Novia Care Clinics, http://www.noviacareclinics.com (lasted visited Dec. 31, 2008).

248. Id.

249. Id.

250. Leslie Condre and Floyd Hindbaugh, Novia CareClinics Opens Offices for Elkhart County Government, www.noviacareclinics.com/news.cfm/ID/1 (lasted visited Dec. 31, 2008).

251. Id. 
which governments pay out in health care related expenses. States may save by implementing clinics into government agencies for employees to utilize as well as implementing them throughout the state for citizens who are insured by state health insurance plans, such as HIP, to use. Such clinics help cut overhead medical costs.

For example, the Elkhart County Government, the first government entity to contract for and provide Novia's on-site health care services in Indiana, has utilized the services by building an on-site clinic for its employees to use. ${ }^{252}$ Novia's services offer "the 880 employees and retirees on the Eklhart County medical plan[] a full range of health and wellness benefit services." ${ }^{253}$ Employees receiving coverage from the county's health insurance plan will receive the following benefits: "[c]onvenient access to primary care physician services with no co-pays or deductibles[; $t$ ]he ability to receive commonly used generic prescription drugs[; and a]ccess to health risk assessments, educational programs, and wellness initiatives which are intended to improve long term health of participating employees." ${ }^{254}$ As a result of the on-site clinic, employees of Elkhart County Government will be healthier and, in the long run, medical expenses are expected to decrease.

Another on-site health care clinic implemented by Novia is in Fishers, Indiana. Faced with escalating health care costs growing about 14 percent annually, the Town of Fishers needed to take immediate action. ${ }^{255}$ Thus, Fishers is erecting a health care clinic in part of its train station for use by town employees. ${ }^{256}$ Officials are hoping the town will save approximately "\$1 million in health-care costs over the next three years." 257 The clinic will allow town employees to visit the clinic for regular check-ups and obtain prescriptions at no cost. ${ }^{258}$ Not only do the employees benefit, but the town saves because the employee visits will cost much less than visits to a doctor's office. ${ }^{259}$ Furthermore, Fishers will be able to purchase medications at wholesale prices, which will save in prescription costs. ${ }^{260}$ Fishers Town Manager Gary Huff opined about Novia's health care clinics by stating, "“[I]t's a very innovative approach, and I think it's where a lot of municipalities will end up...If you don't look at doing some of those things, the health care costs are going to eat you up." 261

Statistically, from July 2007 to July 2008, Fishers paid about $\$ 3.4$ mil-

252. Id.

253. Id.

254. Id.

255. Carrie Ritchie, Town Plans Clinic to Cut Costs," Fishers STAR, December 18, 2008,http://www.indystar.com/article/20081218/LOCAL0102/812180324/1015/LOCAL01.

256. $I d$.

257. Id.

258. Id.

259. Id.

260. $I d$.

261. Ritchie, supra note 255 . 
lion for health care related expenses for its employees. ${ }^{262}$ The town is hoping that health care expenses will decrease by about " $\$ 166,000$ in 2009 ; $\$ 324,000$ in 2010; and $\$ 461,000$ in 2011."263 Further, Fishers anticipates paying approximately $\$ 25$ per month per employee, and incurring minimal expenses for the renovations at the train station. ${ }^{264}$ According to Scott Fadness, co-chairman of the committee that recommended the clinic, " $[t]$ here are very few times in government where you can provide an additional benefit to your employees and also save the town and taxpayers money ... and when you find those opportunities, you need to jump on them right away."” 265

\section{B. CareHere, LLC., Central Tennessee}

CareHere is another on-site clinic management company. As of 2008, CareHere manages more than 60 clinics nationwide. ${ }^{266}$ CareHere integrates wellness and case management with on-site physicians to impact employers that are self-funded with large health care savings. ${ }^{267}$ The Town of Smyma, Tennessee implemented one of CareHere's on-site health care clinics. Smyma employees receive health care from a physician and/or a nurse practitioner at no additional cost, and certain prescriptions are available for free. $^{268}$

Galveston County and the City of Galveston have implemented two of CareHere's health care clinics. ${ }^{269}$ These on-site clinics are expected to have numerous positive effects. In fact, "the clinics are expected to have a positive impact for local taxpayers by trimming government employee health care costs." 270 The expectation is that on-site health care clinics offer a healthier workforce, reduce medical costs to the employer over time, and allow employees to spend more time at work and less time at the doctor's office.

The same savings could be acquired by the Indiana and other state governments if such health care clinics are implemented in states throughout the country as part of state health care plans as well as in state government agencies themselves. Establishing on-site health care clinics in addition to or as a part of HIP could save the state of Indiana millions of

262. Id.

263. Id.

264. Id.

265. Id.

266. About Us, www.carehere.com/about.asp (last visited Dec. 31, 2008).

267. Id.

268. Town of Smyma cuts ribbon for on-site medical clinic, http://www.carehere.com/ includes/downloads/20080828 smyrna.pdf (lasted visited Dec. 31, 2008).

269. Galveston County Employees HealthCare Center, Guidry News. May 8, 2008, http://carehere.com/includes/downloads/05092008_galveston.pdf.

270. Id. 
dollars in health care related costs. ${ }^{271}$ After all, the Town of Fishers alone is expected to save approximately a million dollars in three years.

\section{CONCLUSION}

In conclusion, HIP offers an excellent health insurance model for the states, especially those states struggling to connect their citizens with health care. HIP's model is especially needed during this time of economic downfall when employers are increasingly dropping health care plans for their employees. HIP offers health insurance coverage to Indiana Hoosiers based on market competition, personal responsibility, wellness, and public support while also demanding a modest payment of premiums by the insured based on income. ${ }^{272}$ HIP makes it possible to insure more Hoosiers, but will not deplete the Indiana treasury. HIP supplements employer-sponsored health care insurance, Medicaid/Medicare, Hoosier Healthwise, and other already implemented plans to collectively help decrease the number of uninsured Hoosiers. HIP encourages people to maintain employer-sponsored health care policies, and then works to provide quality and affordable health care to the uninsured.

Furthermore, taking a statewide universal health care coverage approach is not HIP's purpose because that route, like a national universal health care plan, is not currently affordable and/or sustainable. Considering many employers currently offer excellent health care benefits, switching to a statewide universal health care plan may lessen the quality of health care for many individuals because universal coverage would be more expensive and possibly sacrifice quality of care for quantity of persons insured. ${ }^{273} \mathrm{HIP}$ is a plan on which expansion is possible. It does not insure everyone all at once, but starts with a capacity to insure 130,000 people. Through additional innovative practices, however, such as increasing cigarette taxes and inserting on-site health care clinics into the plan, HIP will be able to insure more and more Hoosiers in each year to come. ${ }^{274}$ If other states use HIP as a model and narrowly tailor their health care plans to meet the individual needs of their citizens, as HIP has, the number of uninsured Americans nationwide will likely decrease substantially.

Overall, HIP offers regular and sufficient health care coverage with "name brand" health care insurers. ${ }^{275}$ HIP, along with the buy-in option, takes into account people with different needs and different income levels. HIP does not cover everyone, but is a novel and well-designed plan that has

271. See e.g, Town of Smyma, supra note 254 and Galveston County Employees, supra note 255 (providing examples of savings in health care costs by establishing on-site clinics).

272. See supra §II (details on HIP).

273. See supra §III (comparison of HIP to national universal health care plans).

274. See supra §V (details on on-site health care clinics).

275. See supra §II (details on HIP insurance carriers). 
promising potential and is a first step in the right direction to insuring more Americans. If the HIP framework is more widely adopted, the goal for every American to have health insurance coverage may be more realistically achieved. 
